OPEN ACCESS

Edited by:

Daizy Rani Batish,

Panjab University, India

Reviewed by:

Simerjeet Kaur,

Punjab Agricultural University, India

John Broster,

Charles Sturt University, Australia

*Correspondence:

Lauren M. Schwartz-Lazaro Ilazaro@agcenter.Isu.edu

Specialty section:

This article was submitted to

Weed Management,

a section of the journal

Frontiers in Agronomy

Received: 24 June 2021 Accepted: 11 October 2021

Published: 29 October 2021

Citation:

Patterson KM, Schwartz-Lazaro LM, LaBiche $G$ and Stephenson DO IV (2021) Effects of Narrow-Windrow

Burning on Weed Dynamics in Soybean in Louisiana.

Front. Agron. 3:730280 doi: 10.3389/fagro.2021.730280

\section{Effects of Narrow-Windrow Burning on Weed Dynamics in Soybean in Louisiana}

\author{
Katie M. Patterson ${ }^{1}$, Lauren M. Schwartz-Lazaro ${ }^{1 *}$, Gabrielle LaBiche ${ }^{1}$ and \\ Daniel O. Stephenson IV ${ }^{2}$ \\ ${ }^{1}$ School of Plant, Environmental, and Soil Sciences, Louisiana State University Agricultural Center, Baton Rouge, LA, \\ United States, ${ }^{2}$ Dean Lee Research and Extension Center, Louisiana State University Agricultural Center, Alexandria, \\ LA, United States
}

The soil seedbank allows for long-term persistence of weed species in agricultural fields. Some weed species can persist in the soil seedbank for extended periods. Restricting inputs into the weed seedbank has a large impact on future population density and influences management practices of these weeds in soybean production systems. Harvest weed seed control (HWSC) tactics incorporate mechanical and cultural management strategies to target weed seeds present at harvest. A 3-year trial was initiated to determine if continual use of the HWSC method, narrow windrow burning, selects for earlier seed set and shattering in Louisiana soybean. No shifts in weed populations or shattering time were observed. However, there was a significant reduction in weed density and the weed seed present in the soil seedbank when HWSC and robust herbicide programs were used in combination. Therefore, utilizing multiple effective weed management strategies is imperative in reducing the soil seedbank.

Keywords: integrated weed management, weed ecology, seed shattering, phenology, harvest weed seed control (HWSC)

\section{INTRODUCTION}

Herbicides have played a vital role in increasing global food production by providing the most reliable and least expensive weed management options (Heap, 2014). The over-reliance on herbicides, however, has limited the adoption of integrated weed management (IWM) practices and further intensified the ecological selection pressure contributing to herbicide-resistance (HR) evolution in weeds. Resistance has become widespread to the most commonly used herbicides. In recent years, confirmed cases of resistance to herbicides have been reported in Louisiana for dominant weeds such as Palmer amaranth (Amaranthus palmeri S. Watson), johnsongrass [Sorghum halapense (L.) Pers.], Italian ryegrass [Lolium perenne L. spp. Multiflorum (Lam.) Husnot], waterhemp [Amaranthus tuberculatus (Moq.) Sauer], rice flatsedge (Cyperus iria L.), and barnyardgrass [Echinochloa crus-galli (L.) Beauv.] (Heap, 2021). Reports of HR to more than one site of action has been reported in the mid-southern United States (US) and are an indicator of a bigger problem in the region. Farmers are rapidly losing effective herbicide options, and the current reliance on rotating herbicide sites of action or using herbicide mixtures will not be sufficient to manage weeds in the wake of metabolic resistance to herbicides in weed populations ( $\mathrm{Yu}$ and Powles, 2014). With no new herbicide sites of action likely to be commercially available in the near future, it is critical that weed management be focused on ensuring future effectiveness of the currently used herbicides by employing diversified tactics. 
The soil seedbank allows for long-term persistence of weed species in agricultural fields. Weed communities present in a given soil seedbank are influenced by production practices and environmental conditions (Davis, 2008). Some weed species can persist in the soil seedbank for extended periods. Historically, management strategies have focused on the short-term reduction of the most troublesome weeds in a field based on annual economic thresholds, without a specific focus on the long-term ramifications of soil seedbank management. Restricting the weed seedbank has a large impact on future population density and influences management practices of these weeds in soybean (Glycine max L. Merr) production systems. Maintaining low weed numbers aboveground restricts the soil seedbank, lowers weed impacts on crops, allows for more flexibility within a production system, and reduces selection pressures on weed communities. However, this is difficult with inefficient broadcast herbicide applications, large production areas, weather and time constraints, and typical crop production practices every year (Gage and Schwartz-Lazaro, 2019).

Weed management strategies that incorporate IWM strategies to reduce the risk of developing $\mathrm{HR}$ weeds should include cultural, mechanical, and chemical options that prevent an influx of weed seed into the soil seedbank. United States growers, researchers, and industry representatives can draw from the success of the Australian experience with HR weeds that began over 20 years ago. Australian growers responded to multiple herbicide resistance by incorporating a suite of non-chemical practices, known as harvest weed seed control (HWSC), into their IWM strategies, which allowed them to target weed populations at harvest (Walsh et al., 2013, 2017; Borger et al., 2016). HWSC strategies involve collection and/or destruction of weed seeds during crop harvest, thus minimizing weed seedbank additions. The success of HWSC relies on the propensity of annual weed species to retain seeds until crop harvest (Schwartz-Lazaro et al., 2016, 2017; Walsh et al., 2018a). Previous research has been conducted on the seed retention of 16 broadleaf and 9 grass weed species (Schwartz-Lazaro et al., 2021a,b). Ideal weed species candidates for HWSC were identified and many are economic decision drivers in soybean, wheat (Triticum aestivum L.), and rice (Oryza sativa L.). For example, weed seed retention was greater than $90 \%$ for Palmer amaranth, smooth pigweed (Amaranthus hybridus L.), common lambsquarters (Chenopodium album L.), jimsonweed (Datura stramonium), common cocklebur (Xanthium strumarium L.), and johnsongrass up to 3 weeks after soybean maturity across the majority of states (Schwartz-Lazaro et al., 2021a). Barnyardgrass and junglerice (Echinochloa colona L.) also retained greater than $80 \%$ of seed up to 2 weeks after soybean maturity (SchwartzLazaro et al., 2021b). Modeling studies (Shergill et al., 2020) report greater than $80 \%$ seed retention is needed for HWSC to be viable.

One form of HWSC is narrow-windrow burning (NWB), which funnels the crop residue (both straw and chaff fractions) into a windrow that is then burned (Walsh and Newman, 2007; Walsh et al., 2018b; Shergill et al., 2020). Narrow-windrow burning has been shown to reduce Palmer amaranth inputs into the soil seedbank when used alone but is much more effective when used in conjunction with an efficacious residual activity herbicide program. In soybean, NWB reduced subsequent Palmer amaranth plant density by $73 \%$ and the soil seedbank by $62 \%$ over a period of 3 years in Arkansas (Norsworthy et al., 2016). Harvest weed seed control, as any IWM tactic, has the potential to cause shifts or adaptations to weeds, such as early seed shattering or shifting to a more prostrate growth habit. Very limited research has examined these adaptations for weeds subjected to HWSC in US production systems, especially in seed retention or flowering time (De Wet and Harlan, 1975; Walsh et al., 2018a). Additionally, HWSC has not been widely tested in the midsouthern US and has never been implemented in Louisiana. The additional impact of another form of IWM is imperative to examine in current soybean production systems to evaluate if HWSC can extend the use of currently effective IWM strategies, such as herbicides. Therefore, the objective of this study was to determine if continual HWSC, specifically NWB, is effective in soybean production in Louisiana and if the continual use of this HWSC method selects for earlier seed shattering or seed set.

\section{MATERIALS AND METHODS}

\section{Treatments and Experimental Design}

Field trials evaluating the effects of harvest weed seed control in soybean were conducted from 2018 to 2020, located at the Central Research Station in Baton Rouge, Louisiana and the Dean Lee Research and Extension Center in Alexandria, Louisiana. Experiments were established in a factorial arrangement of treatments in a split plot design with four replications. The main plot was herbicide treatment, and the subplot was with or without NWB. Plot size was $7.6 \times 45.7 \mathrm{~m}$ in all years on $96.5-\mathrm{cm}$ wide rows. All treatments assigned to plots remained the same for all years. Soybean was planted at 288,000 seeds $\mathrm{ha}^{-1}$. Herbicide treatments included with and without a preemergence (PRE) herbicide (flumioxazin at $140.1 \mathrm{~g}$ $\mathrm{ha}^{-1}$, Valor ${ }^{\circledR}$ SX, Valent) followed by a postemergence (POST) herbicide treatment (glufosinate at $2.0 \mathrm{~L} \mathrm{ha}^{-1}$, Liberty ${ }^{\mathrm{TM}}$, Bayer Crop Science). The POST was applied at the V3/V4 soybean growth stage. Additionally, a desiccant (paraquat at $560.4 \mathrm{~g}$ ai ha $^{-1}$, Gramoxone ${ }^{\circledR}$ SL 2.0, Syngenta) was applied 14 days prior to harvest to aid in drying down the soybean for harvestability for all treatments as this is standard practice in Louisiana soybean. A nontreated control (NTC) was included where no PRE or POST herbicide treatments were applied. All herbicide treatments were applied using an air-pressurized tractor-mounted sprayer calibrated to deliver $143 \mathrm{~L} \mathrm{ha}^{-1}$ at $270 \mathrm{kPa}$. Sprayers were fitted with four AIXR110015 flat-fan nozzles (TeeJet Technologies, Springfield, IL) spaced $41 \mathrm{~cm}$ apart. Applications were applied in wind speeds of no more than $4.8 \mathrm{~km} \mathrm{~h}^{-1}$. Further, plots were subjected to with or without NWB treatments after harvest. NWB was conducted by funneling, via a manufactured chute attached to the rear of the combine, the crop residue, both chaff and straw material, into a windrow behind the combine during harvest operations. The material was then burned. The fire was started by a handheld blow torch. The fire was monitored until fully extinguished. 
A

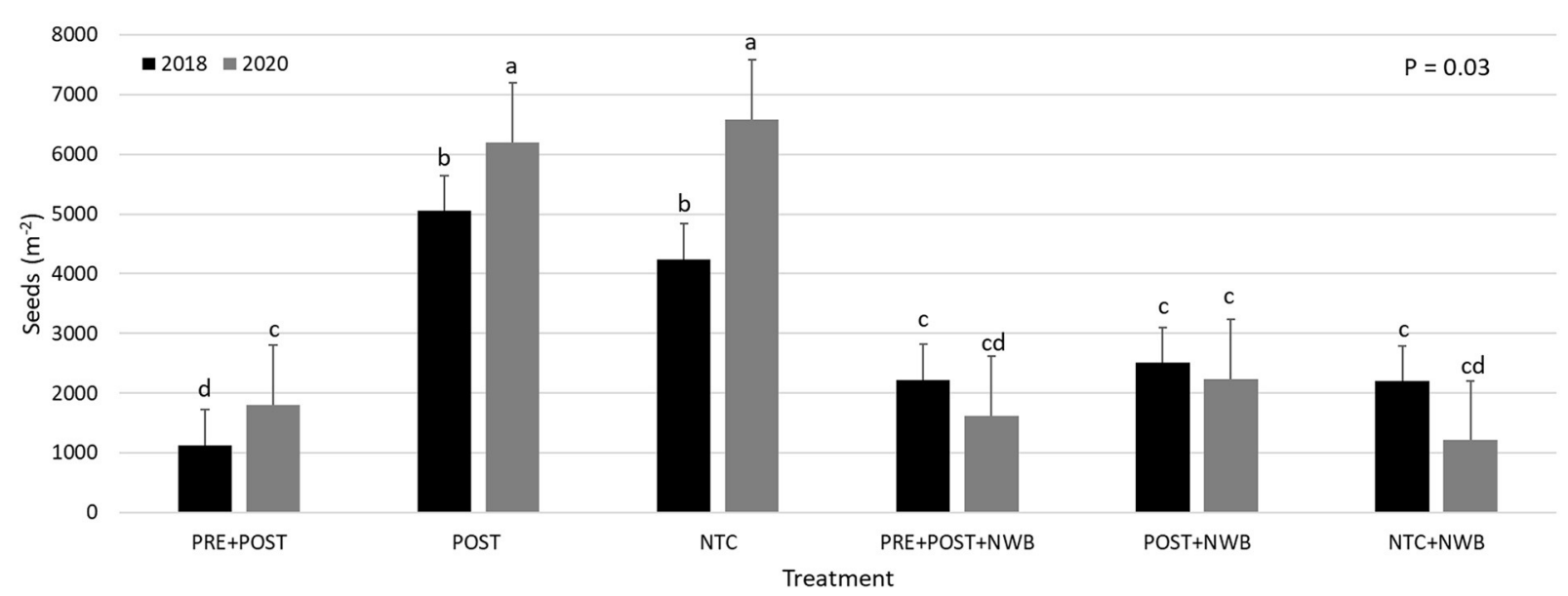

B

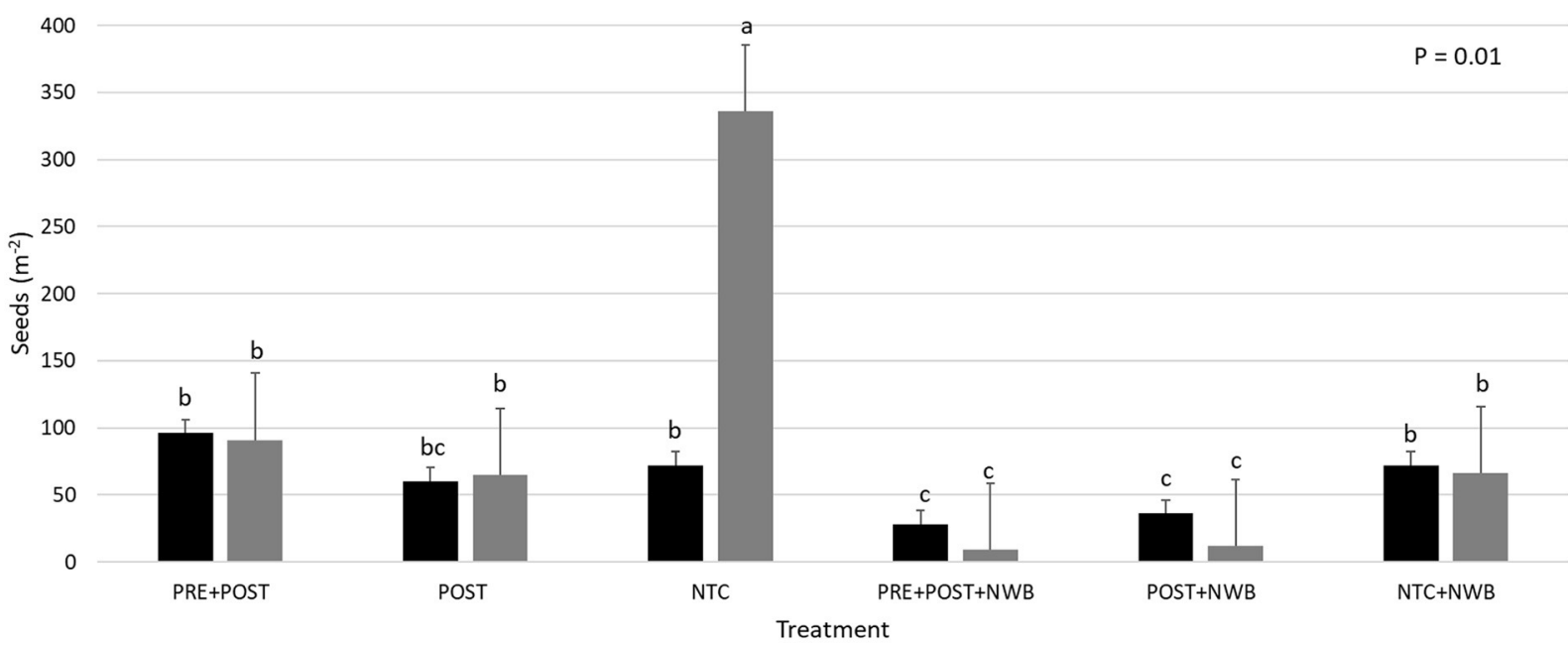

C

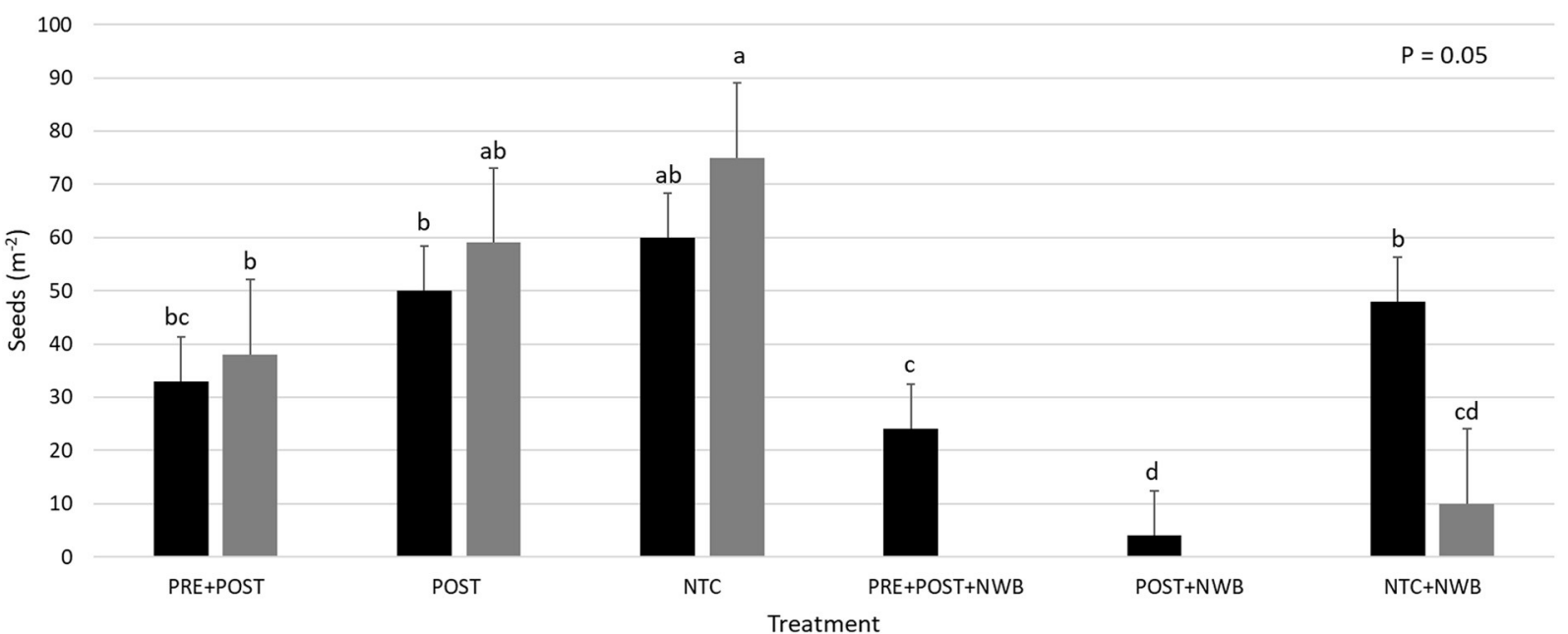

FIGURE 1 | Changes in the soil seedbank from 2018 to 2020 for (A) Amaranthus palmeri, (B) Echinochloa crus-galli, and (C) Ipomoea species based on the interaction of herbicide program and with or without narrow-windrow burning. Sites were pooled since there are no significant difference between them. Means followed by the same letter are not statistically different according to Fisher's protected LSD $(\alpha=0.05)$. 


\section{Observations and Management}

In spring 2018, 12 soil cores, $10.8 \mathrm{~cm}$ wide and $15.2 \mathrm{~cm}$ deep $\left(0.003 \mathrm{~m}^{2}\right.$ of soil surface area), were collected in a $\mathrm{W}$-pattern across each plot to determine a baseline of the soil seedbank. Soil cores were also taken in the subsequent years spring and after harvest in 2020. Four samples were combined for a total of three replications per plot. Soil samples were stored at $-14^{\circ} \mathrm{C}$ for at least 6 weeks before each sample was thawed, de-aggregated, stirred, and distributed over commercial potting mix in a 27.8 $\times 54.5-\mathrm{cm}$ plastic tray (full details in Schwartz et al., 2015). The trays containing the soil samples were placed on a greenhouse bench and irrigated daily to capacity. Seedlings were identified and counted over 4 weeks, after which soils were then allowed to dry fully for 1 week, and the irrigation and germination cycle repeated. After the second germination cycle, soils were stored at $5^{\circ} \mathrm{C}$ or frozen prior to a third germination cycle. Additional data collection of weed densities for the top three weed species were collected prior to the PRE and POST applications and prior to harvest in five $50 \times 50 \mathrm{~cm}$ quadrants per plot. Additionally, within those plots, prior to harvest, the weeds were collected to determine the number of retained weed seed. This was done by threshing and cleaning the seed by hand. Then the total amount of seed was weighed. Ten lots of 100 seeds were counted and weighed. Percent seed retention was then determined by the following equation:

$\%$ seed retention $=[$ total $\#$ of seed $/$ (total $\#$ of seed + germinated seed in soil) ${ }^{*} 100$. Following this the average weight was used to determine the total number of seed retained. Soybean yield, adjusted to $13 \%$ moisture content, was determined.

\section{Statistical Analysis}

Data analyzed were average density of species emerging as seedlings per $450 \mathrm{~cm}^{3}$ soil sample per site. The estimated total number of seeds plant ${ }^{-1}$, seedling emergence, and percent seed retention (calculated as in Schwartz-Lazaro et al., 2016) were analyzed with a two-way ANOVA using a mixed model analysis procedure in SAS 9.3 (SAS Institute Inc., Cary, NC) with mean separations based on Fisher's LSD values $(\alpha=0.05)$. Species and year were the fixed effects, while site location was a random effect in the model. There was no significant difference between years for percent seed retention, thus a correlation analysis was performed to determine if a combination of variables affected seed retention.

\section{RESULTS}

Site effect was not significant for both herbicide treatment and NWB, thus sites were pooled. No shifts in weed populations or weed seed shattering time were observed during the 3-year experiment. However, a significant reduction in the aboveground weed density $(P<0.0001)$ and weed seedbank $(P=0.001)$ were observed with the added use of NWB. Without the use of $\mathrm{NWB}$, an average of 28 and $6 \%$ increase in the amount of weed seeds entering the soil seedbank was observed in the POST only and PRE fb POST treatments, respectively (Figure 1). The use of NWB with both herbicide programs and the NTC showed a decrease in weed seed density per $\mathrm{m}^{-2}$. A change similar
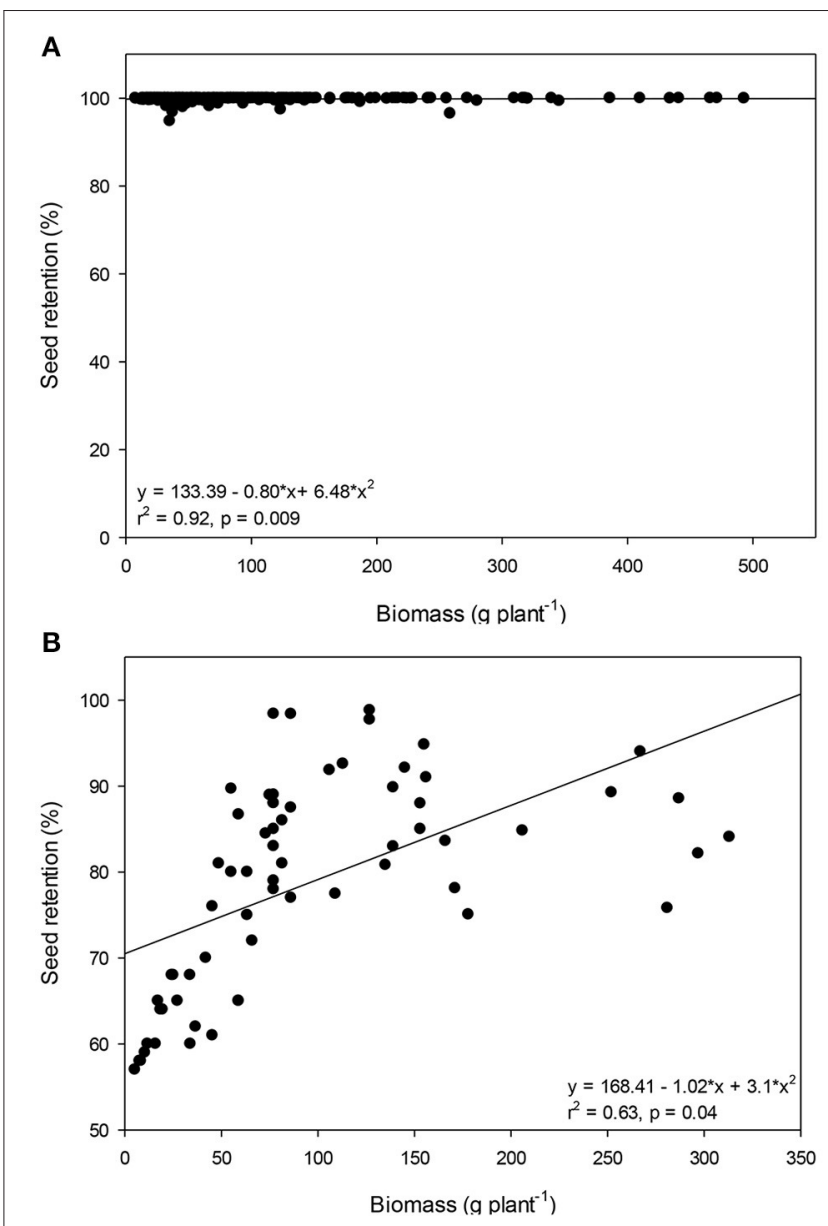

FIGURE 2 | Mean percent seed retention for (A) Amaranthus palmeri and (B) Echinochloa crus-galli by biomass $\left(g\right.$ plant $^{-1}$ ). Data pooled across years and sites.

to that of Palmer amaranth was still observed (Figure 1A), but barnyardgrass (Figure 1B) and morningglory (Figure 1C) species both had less significant changes in density.

Narrow-windrow burning had no significant effect $(P=\mathrm{NS})$ on seed retention or when shattering began. In addition, the same trend of seed retention was observed regardless of the herbicide program. The number of seeds did vary significantly. Across all sites and years, seed retention did not show significant changes in Palmer amaranth as $>98 \%$ of the seeds were retained (Figure 2A). However, in barnyardgrass, plants with smaller biomass retained less seed compared to plants with a larger biomass (Figure 2B). Palmer amaranth plants seed production ranged from 122 to 3,542 seeds plant ${ }^{-1}$. Both barnyardgrass and morningglory species produced $<300$ and 50 seeds per plant, respectively.

A significant interaction was observed between herbicide treatment and NWB $(P=0.001)$ for weed density (Figure 3). Palmer amaranth density at harvest varied and followed a similar trend as the soil seedbank. From 2018 to 2020, NTC + NWB treatment increased by $33 \%$ in the number of plants, which is 


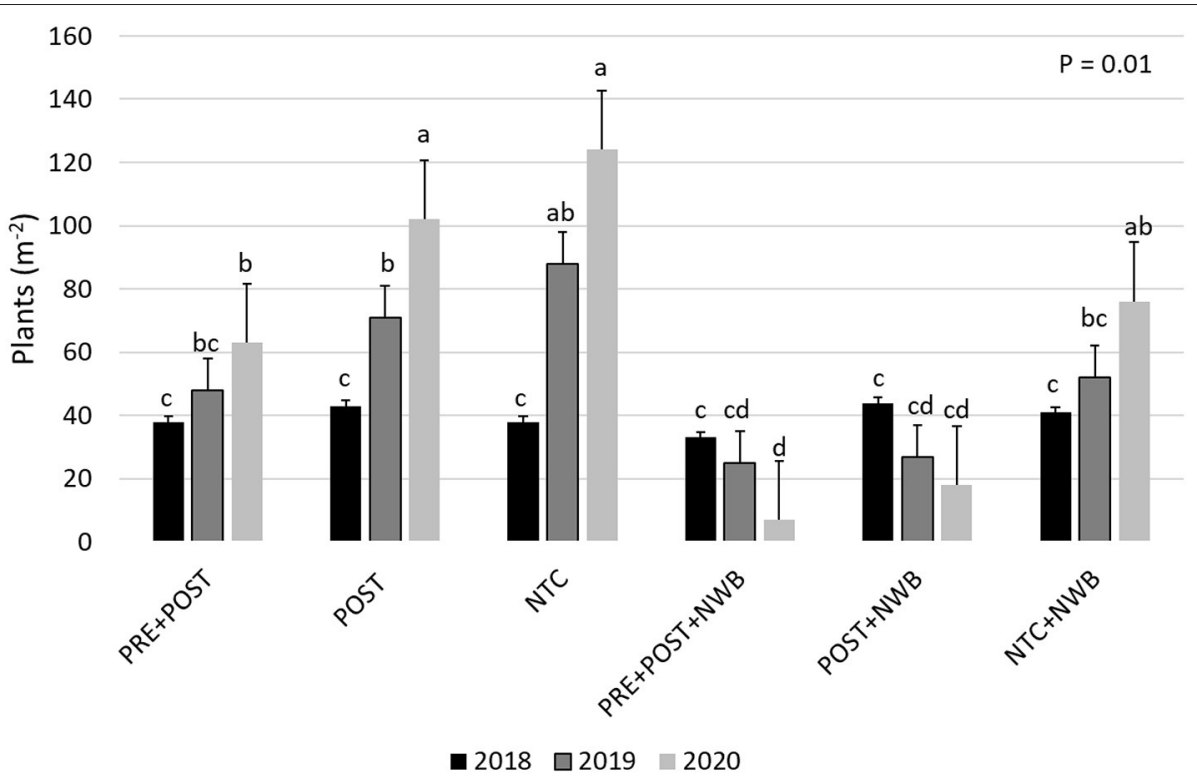

FIGURE 3 | Final weed density for Amaranthus palmeri at soybean harvest from 2018 to 2020 for each herbicide treatment with and without narrow-windrow burning. Means followed by the same letter are not statistically different according to Fisher's protected LSD $(\alpha=0.05)$.

inconsistent with seeds per $\mathrm{m}^{2}$ in Palmer amaranth (Figure 1A). This could be due to Palmer amaranth having multiple flushes of germination throughout the growing season and that additional plants were in the windrows. However, NWB alone was $62 \%$ more effective in reducing the seedbank that contributes to the aboveground weed populations than no control options at all. After 3 years, a POST only treatment increased from about 40 seed to 100 seeds $\mathrm{m}^{2}$, whereas with the addition of NWB, the same program decreased from an average of 42 seeds to 18 seeds $\mathrm{m}^{2}$. All three weed species showed a similar trend, thus only Palmer amaranth is shown. The added use of an additional IWM tactic decreases the overall density of weeds or weed seeds above or belowground. Soybean yield (2018: 2,636.2 $\pm 158.4 \mathrm{~kg} \mathrm{ha}^{-1}$, 2019: $\left.2,723.7 \pm 121.1 \mathrm{~kg} \mathrm{ha}^{-1}, 2020: 2,452.6 \pm 117.4 \mathrm{~kg} \mathrm{ha}^{-1}\right)$ was not affected $(P=\mathrm{NS})$ by the use of NWB or with herbicide programs examined.

\section{DISCUSSION}

Weed seed shattering is a problem that faces all agricultural systems world-wide and is the greatest contributor to increase the soil seedbank and subsequently weed emergence, including HR weeds. For example, some of the most problematic broadleaf weeds in United States production of corn (Zea mays L.) and soybean [Glycine max (L.)] include Palmer amaranth, waterhemp, giant ragweed (Ambrosia trifida L.), common lambsquarters (Chenopodium album L.), and morningglory species (Ipomoea spp.) (Van Wychen, 2015, 2016). Approximately $<50 \%$ of seeds in these weed species are shattered with the crop harvest window (Davis, 2008; Goplen et al., 2016; Schwartz-Lazaro et al., 2021a,b). In Minnesota, it was observed that by the time $75 \%$ of soybeans were harvested giant ragweed retained $80 \%$ of its total seeds (Goplen et al., 2016). In a survey across five US states, Palmer amaranth and common waterhemp retained up to $95 \%$ of its seed at soybean maturity (Schwartz-Lazaro et al., 2016). This is consistent with the findings for Palmer amaranth in this study. However unlike in this study, ivyleaf morningglory (Ipomoea hederacea Jacq.) has been shown to retain 85 and $75 \%$ of its seed in soybean and corn production in Illinois, respectively (Davis, 2008). Seed retention for morninnglory species, in this study, is more consistent with seed retention studies conducted by Schwartz-Lazaro et al. (2021a) where there was more than $98 \%$ seed retention.

Flowering time and subsequent seed production in weeds are subject to variability based on emergence timing, environmental factors (i.e., precipitation, temperature, and wind), and management practices (i.e., crop selection, crop planting date, seeding rate, etc.), which can directly be observed in the density of weeds that emerge each year (Kryvokhyzha et al., 2016). Previous research has shown that in delayed harvest scenarios Palmer amaranth and barnyardgrass plants lose a mean of 0.1 and $0.3 \%$ of their seeds daily after soybean harvest, respectively (Schwartz-Lazaro et al., 2017). Additionally, the belowground seedbank has been shown to shift from various selection pressures (Roumet et al., 2013). An example of a newer selection pressure would be HWSC, specifically NWB, which is a management tactic that has not been utilized in US cropping systems long enough to understand its long-term impacts on weed populations both above and belowground. In wheat (Triticum aestivum L.), canola (Brassica napus L.), and lupin (Lupinus angustifolius L.) systems in Australia, NWB has been largely embraced as a tactic for managing rigid ryegrass (Lolium 
rigidum Gaudin) seed and thus decreasing the soil seedbank (Walsh et al., 2013). In Arkansas, NWB was evaluated on nine common weed species in soybean residue. All seeds evaluated were completely destroyed in varying levels of soybean residue $\left(1.08-1.95 \mathrm{~kg} \mathrm{~m}^{-2}\right)$, which effectively is decreasing returns to the soil seedbank (Norsworthy et al., 2020). This additional IWM tactic serves to prolong other effective IWM tactics, such as the use of herbicides which is steadily decreasing, due to the increasing problem of HR weeds.

Evolutionary changes in weeds, however, are difficult to observe in a 3-year timespan (as seen in this research), but conclusions can be drawn regarding the soil seedbank. The soil seedbank is critical to control long-term, although what emerges may not accurately correspond with the belowground seedbank contents (Burnside et al., 1981; Kivilaan and Bandurski, 1981; Omami et al., 1999; Steckel et al., 2007; Jha et al., 2014; Korres et al., 2018). Due to this dormancy, as well as other factors such as burial depth and environmental conditions, the aboveground weed populations will not accurately represent the belowground seedbank and management practices should reflect this. The soil core samples taken, in this study, illustrate this in Palmer amaranth specifically, as there were 37 times more Palmer amaranth weed seeds found in the soil seedbank than what emerged initially.

\section{CONCLUSIONS}

As with each management tactic, the advantages and disadvantages must be addressed. Narrow-windrow burning has several benefits including the low up-front cost of setting up a NWB chute, all weed seeds that enter the combine will end up in the windrow thus reducing the number of seeds returned to the soil seedbank and ultimately would reduce the number of weeds present in the field, and the ease of adoption as burning is already used in several cropping systems. Several disadvantages must be considered with NWB including the concern of fire escapes,

\section{REFERENCES}

Borger, C. P. D., Reithmuller, G., and D’Antuono, M. (2016). Eleven years of integrated weed management: long-term impacts of row spacing and harvest weed seed destruction on Lolium rigidum control. Weed Res. 56, 359-366. doi: $10.1111 /$ wre. 12220

Burnside, O. C., Fenster, C. R., Evetts, L. L., and Mumm, R. F. (1981). Germination of exhumed weed seed in Nebraska. Weed Sci. 29, 577-586.

Davis, A. S. (2008). Weed seed pools concurrent with corn and soybean harvest in Illinois. Weed Sci. 56, 503-508. doi: 10.1614/WS-07-195.1

De Wet, J. M. J., and Harlan, J. R. (1975). Weeds and domesticates: evolution in the man-made habitat. Econ. Bot. 29, 99-108. doi: 10.1007/BF02863309

Gage, K. L., and Schwartz-Lazaro, L. M. (2019). Shifting the paradigm: an ecological systems approach to weed management. Agriculture 9:137. doi: 10.3390/agriculture9080179

Goplen, J. J., Sheaffer, C. C., Becker, R. L., Coulter, J. A., Breitenbach, F. R., Behnken, L. M., et al. (2016). Giant ragweed (Ambrosia trifida) seed production and retention in soybean and field margins. Weed Technol. 30, 246-253. doi: 10.1614/WS-D-16-00084.1

Heap, I. (2014). Global perspective of herbicide-resistant weeds. Pest Manage. Sci. 70, 1306-1315. doi: 10.1002/ps.3696 smoke, nutrient removal specifically carbon, and residue removal which would lead the soil bare. The additional non-chemical IWM practice, that NWB would bring, allows for stewardship of other weed management practices to be done. However, NWB alone is not effective enough to control weed populations and does still allow inputs back into the soil seedbank. The use of HWSC methods combined with effective herbicide programs can improve weed control both above and belowground. While this HWSC tactic has shown some success, more research is needed to understand the long-term impacts in US cropping systems. Preservation of all management tactics, both chemical and non-chemical is critical in maintaining sound and efficacious agricultural practices.

\section{DATA AVAILABILITY STATEMENT}

The raw data supporting the conclusions of this article will be made available by the authors, without undue reservation.

\section{AUTHOR CONTRIBUTIONS}

KP and DS: writing. LS-L: conceptualization, methodology, analysis, and writing. GL: data collection and writing. All authors contributed to the article and approved the submitted version.

\section{FUNDING}

Funding for this project was provided by the Louisiana Soybean and Grain Research and Promotion Board (Award-002306).

\section{ACKNOWLEDGMENTS}

The authors would like to thank the research staff at the Central Research Station and the Dean Lee Research and Extension Center for their efforts. Additionally, we would like to thank the student workers for their assistance with this project.

Heap, I. (2021). The International Survey of Herbicide-Resistant Weeds. Weed Science Society of America. Available online at: https://www.weedscience.org/ Home.aspx (accessed May 6, 2021).

Jha, P., Norsworthy, J. K., and Garcia, J. (2014). Depletion of an artificial seed bank of Palmer amaranth (Amaranthus palmeri) over four years of burial. Am. J. Plant Sci. 5, 1599-1606. doi: 10.1614/WS-07-174.1

Kivilaan, A., and Bandurski, R. S. (1981). The one-hundred-year period for Dr Beal's seed viability experiment. Am. J. Bot. 68, 1290-1292.

Korres, N. E., Norsworthy, J. K., Young, B. G., Reynolds, D. B., Johnson, W. G., Conley, S. P., et al. (2018). Seedbank persistence of Palmer amaranth (Amaranthus palmeri) and waterhemp (Amaranthus tuberculatus) across diverse geographical regions in the United States. Weed Sci. 66, 446-456. doi: 10.1017/wsc.2018

Kryvokhyzha, D., Holm, K., Chen, J., Cornille, A., Glémin, S., Wright, S. I., et al. (2016). The influence of population structure on gene expression and flowering time variation in the ubiquitous weed Capsella bursa-pastoris (Brassicaceae). Mol. Ecol. 25, 1106-1121. doi: 10.1111/mec.13537

Norsworthy, J. K., Green, J. K., Barber, T., Roberts, T. L., and Walsh, M. J. (2020). Seed destruction of weeds in southern US crops using heat and narrow-windrow burning. Weed Technol. 34, 589-596. doi: 10.1017/wet. 2020.36 
Norsworthy, J. K., Korres, N. E., Walsh, M. J., and Powles, S. B. (2016). Integrating herbicide programs with harvest weed seed control and other fall management practices for the control of glyphosate-resistant Palmer amaranth (Amaranthus palmeri). Weed Sci. 64, 540-550. doi: 10.1614/WS-D-15-00210.1

Omami, E. N., Haigh, A. M., Medd, R. W., and Nicol, H. I. (1999). Changes in germinability, dormancy and viability of Amaranthus retroflexus as affected by depth and duration of burial. Weed Res. 39, 345-354.

Roumet, M., Noilhan, C., Latreille, M., David, J., and Muller, M. H. (2013). How to escape from crop-to-weed gene flow: phenological variation and isolationby-time within weedy sunflower populations. New Phytol. 197, 642-654. doi: $10.1111 /$ nph. 12045

Schwartz, L. M., Gibson, D. J., Gage, K. L., Matthews, J. L., Jordan, D. L., Owen, M. D. K., et al. (2015). Seedbank and field emergence of weeds in glyphosateresistant cropping systems in the United States. Weed Sci. 63, 425-439. doi: 10.1614/WS-D-14-00089.1

Schwartz-Lazaro, L. M., Green, J. K., and Norsworthy, J. K. (2017). Seed retention of Palmer amaranth (Amaranthus palmeri) and barnyardgrass (Echinochloa crus-galli) in soybean. Weed Technol. 31, 617-622. doi: 10.1017/wet.2017.25

Schwartz-Lazaro, L. M., Norsworthy, J. K., Young, B. G., Bradley, K. W., Kruger, G. R., Davis, V. M., et al. (2016). Tall waterhemp (Amaranthus tuberculatus) and Palmer amaranth (Amaranthus palmeri) seed production and retention at soybean maturity. Weed Technol. 30, 284-290. doi: 10.1614/WT-D-15-00130.1

Schwartz-Lazaro, L. M., Shergill, L. S., Evans, J. A., Bagavathiannan, M. V., Beam, S. C., Bish, M. D., et al. (2021a). Seed shattering phenology at soybean harvest of economically important weeds in multiple regions of the United States. Part 1: broadleaf species. Weed Sci. 69, 95-103. doi: 10.1017/wsc.2020.80

Schwartz-Lazaro, L. M., Shergill, L. S., Evans, J. A., Bagavathiannan, M. V., Beam, S. C., Bish, M. D., et al. (2021b). Seed shattering phenology at soybean harvest of economically important weeds in multiple regions of the United States. Part 2: grass species. Weed Sci. 69, 104-110. doi: 10.1017/wsc.2020.79

Shergill, L. S., Schwartz-Lazaro, L. M., Leon, R., Ackroyd, V. J., Flessner, M. L., Bagavathiannan, M., et al. (2020). Current outlook and future research needs for harvest weed seed control in North American cropping systems. Pest Manag. Sci. 76, 3887-3895. doi: 10.1002/ps.5986

Steckel, L. E., Sprague, C. L., Stoller, E. W., Wax, L. M., and Simmons, F. W. (2007). Tillage, cropping system, and soil depth effects on common waterhemp (Amaranthus rudis) seed-bank persistence. Weed Sci. 55, 235-239. doi: 10.1614/WS-06-198

Van Wychen, L. (2015). Baseline Survey of the Most Common and Troublesome Weeds in the United States and Canada. Weed Science Society of America. Available online at: http://wssa.net/wp-content/uploads/2015-Weed-Survey_ Baseline.xlsx (accessed June 2, 2021).

Van Wychen, L. (2016). Weed Science Society of America. Survey of the most common and troublesome weeds in broadleaf crops, fruits and vegetables in the United States and Canada. Weed Science Society of America. Available online at: http://wssa.net/wp-content/uploads/2016_Weed_Survey_Final.xlsx (accessed June 2, 2021).

Walsh, M., and Newman, P. (2007). Burning narrow windrows for weed seed destruction. Field Crops Res. 104, 24-30. doi: 10.1016/j.fcr.2007. 05.012

Walsh, M., Newman, P., and Powles, S. (2013). Targeting weed seeds in-crop: a new weed control paradigm for global agriculture. Weed Technol. 27, 431-436. doi: 10.1614/WT-D-12-00181.1

Walsh, M., Ouzman, J., Newman, P., Powles, S., and Llewellyn, R. (2017). High levels of adoption indicate that harvest weed seed control is now an established weed control practice in Australian cropping. Weed Technol. 31, 341-347. doi: 10.1017/wet.2017.9

Walsh, M. J., Broster, J. C., Aves, C., and Powles, S. B. (2018a). Influence of crop competition and harvest weed seed control on rigid ryegrass (Lolium rigidum) seed retention height in wheat crop canopies. Weed Sci. 66, 627-633. doi: 10.1017/wsc.2018.28

Walsh, M. J., Broster, J. C., Schwartz-Lazaro, L. M., Norsworthy, J. K., Davis, A. S., Tidemann, B. D., et al. (2018b). Opportunities and challenges for harvest weed seed control in global cropping systems. Pest Manag. Sci. 74, 2235-2245. doi: $10.1002 /$ ps.4802

Yu, Q., and Powles, S. (2014). Metabolism-based herbicide resistance and cross-resistance in crop weeds: a threat to herbicide sustainability and global crop production. Plant Physiol. 166, 1106-1118. doi: 10.1104/pp.114. 242750

Conflict of Interest: The authors declare that the research was conducted in the absence of any commercial or financial relationships that could be construed as a potential conflict of interest.

Publisher's Note: All claims expressed in this article are solely those of the authors and do not necessarily represent those of their affiliated organizations, or those of the publisher, the editors and the reviewers. Any product that may be evaluated in this article, or claim that may be made by its manufacturer, is not guaranteed or endorsed by the publisher.

Copyright $\odot 2021$ Patterson, Schwartz-Lazaro, LaBiche and Stephenson. This is an open-access article distributed under the terms of the Creative Commons Attribution License (CC BY). The use, distribution or reproduction in other forums is permitted, provided the original author(s) and the copyright owner(s) are credited and that the original publication in this journal is cited, in accordance with accepted academic practice. No use, distribution or reproduction is permitted which does not comply with these terms. 